\title{
PENGEMBANGAN SEKOLAH RAMAH ANAK DI TINGKAT PENDIDIKAN ANAK USIA DINI
}

\author{
Tusriyanto \\ Institut Agama Islam Negeri (IAIN) Metro \\ Email: tusriyanto@metrouniv.ac.id
}

\begin{abstract}
The phase of children aged 0-6 years (golden age) is a period where children must get special education so that their physical and mental growth and development are appropriate in order to be able to receive and respond to stimulation obtained from the environment. The most important thing that must be carried out by the management of education, especially at the level of Early Childhood Education is to seek Child Friendly Schools. Child-friendly schools are defined as an open school concept, trying to apply learning that pays attention to students' psychological and psychological development. The development of SRA can be implemented in Early Childhood Education (PAUD), through collaboration from families, communities and schools.
\end{abstract}

Keywords: Child Friendly School, family, community, and PAUD

\begin{abstract}
Abstrak
Fase anak usia 0-6 tahun (golden age) adalah masa dimana anak harus mendapatkan pendidikan khusus agar pertumbuhan dan perkembangan fisik maupun mentalnya secara tepat agar mampu menerima dan memberi respon terhadap stimulasi yang didapatkan dari lingkungan. Hal terpenting yang harus dilakukan pengelolan pendidikan khususnya di tingkat Pendidikan Anak Usia Dini adalah mengupayakan Sekolah Ramah Anak (SRA). Sekolah ramah anak diartikan sebagai sebuah konsep sekolah yang terbuka, berusaha mengaplikasi pembelajaran yang memperhatikan perkembangan psikis maupun psikologis siswanya. Pengembangan SRA dapat dilaksanakan pada Pendidikan Anak Usia Dini (PAUD), melalui kerjasama dari keluarga, masyarakat maupun sekolah.
\end{abstract}

Kata kunci: Sekolah Ramah Anak, keluarga, masyarakat, dan PAUD

\section{A. Pendahuluan}

Usia prasekolah atau balita merupakan fase yang sangat fundamental bagi perkembangan individu. Usia balita sebagai masa terbentuknya kepribadian dasar individu, usia prasekoah sebagai masa yang penuh dengan kejadiankejadian penting dan unik (a highly eventful and unique period of life) yang meletakkan dasar bagi kehidupan seseorang di masa dewasa. Fernie menyakini bahwa pengalaman-pengalaman belajar awal tidak akan pernah bisa diganti oleh pengalaman-pengalaman berikutnya, kecuali dimodifikasi. Goleman menjelaskan bahwa periode tiga atau empat tahun pertama merupakan periode subur bagi pertumbuhan otak manusia hingga dapat mencapai kurang lebih dua pertiga dari ukuran otak orang dewasa. ${ }^{1}$

1 Kristanto, dkk. Identifikasi Model Sekolah Ramah Anak (Sra) Jenjang Satuan Pendidikan Anak Usia Dini Se-Kecamatan Semarang Selatan. Artikel dimuat dalam jurnal "Jurnal Penelitian PAUDIA", Volume 1 No. 1 Tahun 2011. 
Anak berusia 0-6 tahun (golden age) perlu mendapat perhatian khusus karena masa tersebut merupakan masa terjadinya perkembangan dan pertumbuhan yang pesat sekaligus kritis karena merupakan langkah awal masa depan anak. Masa ini adalah suatu proses menuju kematangan fisik dan mental sehingga mereka siap menerima dan memberi respon terhadap stimulasi yang didapatkan dari lingkungan. Menurut Laurens, lingkungan fisik sekitar seseorang sangat mempengaruhi mental dan perilakunya. Segala informasi dan stimulasi dari lingkungan akan langsung diterima sehingga memberikan pengaruh yang besar di kehidupan mereka. ${ }^{2}$ Dengan demikian, jelaslah bahwa pada masa anak usia dini merupakan fase yang harus diperhatikan secara serius bagi pendidik, orang tua, serta semua pihak yang terlibat dalam pendidikan karena merupakan fase yang sangat penting bagi perkembangan anak menuju fase selanjutnya.

Berikut adalah gambaran lingkungan awal yang mempengaruhi pertumbuhan dan perkembangan anak menurut Sari:

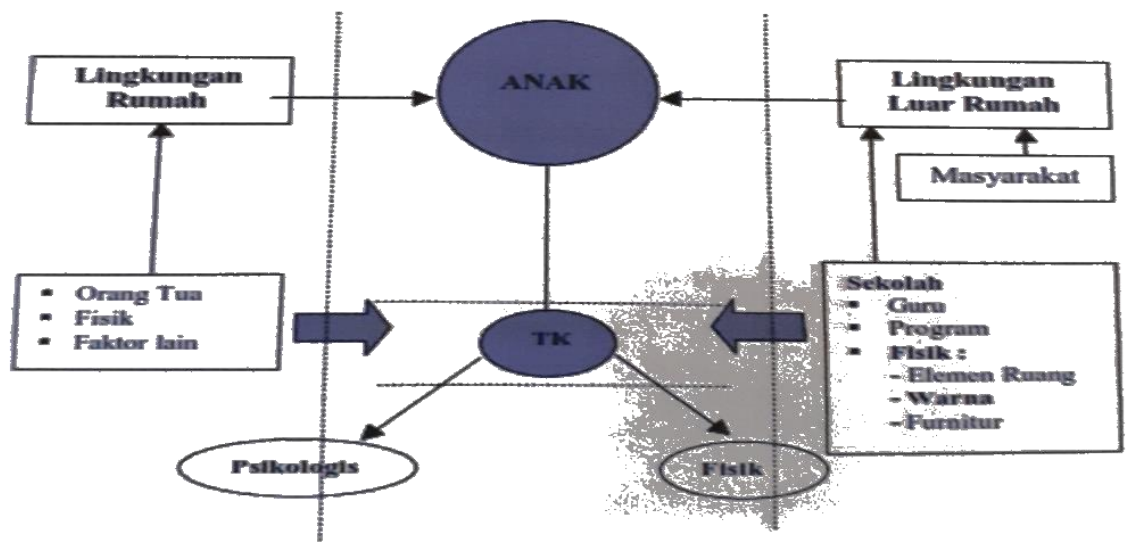

Gambar 1. Lingkungan yang mempengaruhi perkembangan anak (sumber: Sari, 2009)

Berdasarkan gambar diatas terlihat jelas lingkungan yang mepengaruhi pertumbuhan dan perkembangan anak terbagi menjadi dua, yaitu lingkungan rumah (orang tua, fisik, faktor lain) serta lingkungan luar rumah (masyarakat dan lembaga formal: RA, dll.). Laurens menjelaskan bahwa setiap kelompok memiliki kebutuhan dasar yang berbeda sesuai penggunanya. Kebutuhan dasar anak-anak dalam berperilaku dalam sebuah lingkungan fisik berbeda dengan orang dewasa sehingga dalam sebuah lingkungan fisik pada suatu RA, dibutuhkan perlakuan yang sesuai dengan anak. ${ }^{3}$ Intinya untuk mendapatkan pendidikan yang terbaik bagi anak usia dini (RA/TK/PAUD) diperlukan kerjasama dari orang tua, masyarakat dan sekolah.

Selanjutnya, menurut Ornstein tentang fungsi belahan otak, salah satunya, menunjukkan bahwa anak yang pada masa prasekolahnya mendapat

2 Ayu Oktira Diyanti, dkk. Lingkungan Ramah Anak pada Sekolah Taman Kanak-Kanak. Dimuat dalam “Jurnal RUAS” Vol. 12 No. 2, Desember 2014.

${ }^{3}$ Ibid. 
rangsangan yang cukup dalam mengembangkan kedua belah otaknya akan memperoleh kesiapan yang menyeluruh untuk belajar secara sukses di saat memasuki SD. Marcon menjelaskan bahwa kegagalan anak dalam belajar pada tahap awal akan menjadi prediktor penting bagi kegagalan belajar pada kelaskelas berikutnya. Begitu pula, kekeliruan belajar awal bisa menjadi penghambat bagi proses belajar selanjutnya. ${ }^{4}$ Hal lain yang menjadi faktor pentingnya pendidikan anak usia dini dilihat dari tuntutan-tuntutan non-edukatif lainnya. Dewasa ini tidak jarang di antara orang tua khusunya di kota-kota besar, yang keduanya menghabiskan sebagian besar waktu mereka di kantor, tempat kerja, atau untuk kepentingan bisnis. Sementara itu, kakek, nenek, atau saudarasaudara lainnya tidak lagi berada di samping mereka. Atau kalau pun ada, mereka semua juga sibuk dengan urusan masing-masing. Perubahan pola dan sikap hidup serta struktur keluarga tersebut menuntut masyarakat untuk segera memasukkan anak-anak mereka ke lembaga pendidikan atau penitipan anak secara dini.

Budaya belajar harus menjadi "Petualangan seumur hidup" dan "Perjalanan eksplorasi tanpa akhir", sehingga pertumbuhan seluruh kepribadian terintegrasi dengan nilai-nilai yang dipelajari. Dengan demikian "Belajar" akan menjadi sangat bermakna dan mampu mencetak pribadi-pribadi berkualitas yang lebih dikenal dengan konsep pendidikan ramah anak yang selanjutnya akan disebut sekolah ramah anak. ${ }^{5}$ Sekolah ramah anak adalah sebuah konsep sekolah yang terbuka, berusaha mengaplikasi pembelajaran yang memperhatikan perkembangan psikis maupun psikologis siswanya. Mengembangkan kebiasan belajar sesuai dengan kondisi psikis dan kejiwaan anak. Ditambahkan pula Aqib model sekolah ramah anak lebih banyak memberikan prasangka baik kepada anak, guru menyadari tentang potensi yang berbeda dari semua peserta didiknya sehingga dalam memberikan kesempatan kepada siswanya dalam memilih kegiatan dan aktivitas bermain yang sesuai minatnya.

Partisipasi adalah hak untuk bertindak yang digunakan siswa untuk mengungkapkan kebebasan berpendapat, bertanya, berargumentasi, berperan aktif di kelas dan di sekolah. Kebebasan berekspresi, bertanya, menjawab harus ditanamkan sejak anak usia dini karena pada usia ini karakter individu mulai terbentuk. ${ }^{6}$ Berdasarkan hal tersebut di atas, maka pengembangan Sekolah Ramah Anak (SRA) khususnya di tingkat pendidikan anak usia dini (RA/TK/PAUD) merupakan suatu keniscayaan agar dapat membantu anak menyelesaikan pertumbuhan dan perkembangan fisik maupun mentalnya secara

${ }^{4}$ Kristanto, dkk. Identifikasi Model Sekolah Ramah Anak (Sra) Jenjang Satuan Pendidikan Anak Usia Dini Se-Kecamatan Semarang Selatan. Artikel dimuat dalam jurnal "Jurnal Penelitian PAUDIA", Volume 1 No. 1 Tahun 2011.

${ }^{5}$ Ibid.

6 Senowarsito, dkk., Implementasi Pendidikan Ramah Anak Dalam Konteks Membangun Karakter Siswa Di Sekolah Dasar Negeri Di Kota Semarang. Artikel ini dimuat dalam "FPBS IKIP PGRI Semarang" Vol. 6 No. 1 Tahun 2012. 
tepat agar mampu menerima dan memberi respon terhadap stimulasi yang didapatkan dari lingkungan.

\section{B. Sekolah Ramah Anak}

\section{Pengertian Sekolah Ramah Anak}

Menurut Kristanto, Sekolah Ramah Anak adalah sekolah yang terbuka melibatkan anak dan remaja untuk berpartisipasi dalam kehidupan sosial, serta mendorong tumbuh kembang dan kesejahteraan anak. ${ }^{7}$ Menurut Ratnasari Sekolah Ramah Anak dapat diartikan sebagai sekolah atau tempat pendidikan yang secara sadar menjamin dan memenuhi hak-hak anak dalam setiap aspek kehidupan secara terencana dan bertanggung jawab.8 Sekolah Ramah Anak adalah program untuk mewujudkan kondisi aman, bersih, sehat, peduli, dan berbudaya lingkungan hidup, yang mampu menjamin pemenuhan hak dan perlindungan anak dari kekerasan, diskriminasi, dan perlakuan salah lainnya, selama anak berada di satuan pendidikan, serta mendukung partisipasi anak terutama dalam perencanaan, kebijakan, pembelajaran dan pengawasan. ${ }^{9}$ Dengan demikian Sekolah Ramah Anak bukanlah membangun atau membuat sekolah baru, tetapi menjadikan sekolah menjadi tempat nyaman bagi anak, serta memastikan sekolah memenuhi hak anak dan melindunginya, karena sekolah menjadi rumah kedua bagi anak, setelah rumahnya sendiri.

Adapun dasar pengembangan Sekolah Ramah Anak adalah "Pasal 4 UU No.23/2002 tentang Perlindungan Anak disebutkan setiap anak berhak untuk dapat hidup tumbuh, berkembang, dan berpartisipasi secara wajar sesuai dengan harkat dan martabat kemanusiaan, serta mendapatkan perlindungan dan kekerasan dan diskriminasi. Salah satu hak dasar anak tersebut adalah hak berpartisipasi yang diartikan sebagai hak untuk mengeluarkan pendapat dan didengarkan suaranya. Anak mempunyai posisi yang strategis". Menurut Hariwijaya dalam keluarga, anak adalah prioritas utama sebagai tumpuan masa depan keluarga. Pada anak seluruh harapan dan cita-cita orang tua tertumpah. Namun seringkali hal ini menjadi beban berat yang harus dipikul oleh anak. Manakala orang tua menjadikan anak sebagai pelampiasan obsesi mereka yang belum tercapai. Anak dijadikan sarana untuk mengejawantahkan impian

7 Kristanto, dkk. Identifikasi Model Sekolah Ramah Anak (Sra) Jenjang Satuan Pendidikan Anak Usia Dini Se-Kecamatan Semarang Selatan. Artikel dimuat dalam jurnal "Jurnal Penelitian PAUDIA", Volume 1 No. 1 Tahun 2011.

8 Ratnasari, dkk. Implementasi Penerapan Sekolah Ramah Anak Pada Penyelenggaraan Pendidikan Sekolah Dasar. Artikel dimuat dalam "The 5th Urecol Proceeding", UAD Yogyakarta 18 Februari 2017.

9 Kementerian Pemberdayaan Perempuan dan Perlindungan Anak RI. Panduan Sekolah Ramah Anak. Deputi Tumbuh Kembang Anak Kementerian Peberdayaan Perempuan dan Perlindungan Anak Tahun 2015., h. 14. 
mereka. sehingga hal ini menjadi tidak sehat bagi anak, mereka dipaksa berjalan menurut rel yang telah diariskan orang tua mereka tanpa bisa melawan. ${ }^{10}$

Dalam sebuah komunitas anak juga mempunyai posisi yang strategis. Anak adalah "embrio", sebuah komunitas baru. Dengan demikian anak menjadi penentu nasib perjalanan suatu komunitas. Anak juga dipandang sebagai tunas muda yang akan menjadi generasi baru penentu masa depan komunitas. Maka anak harus dipandang dan diberlakukan sebagai komunitas terpilih dalam komunitas besarnya. Anak akan tumbuh dan berkembang dengan optimal bila berada pada lingkungan yang mendukung (lingkungan keluarga, sekolah maupun lingkungan masyarakat sekitarnya). Secara garis besar ada beberapa ruang lingkup dimana anak tinggal dan hidup, dimana lingkungan ini sangat berpengaruh terhadap terciptanya Sekolah Ramah Anak ini. Yang pertama adalah keluarga kemudian lingkungan masyarakat (baik lingkungan desa, kota ataupun negara). Ruang lingkup yang lebih besar lagi adalah dunia internasional.11 Anak akan tumbuh berkembang secara optimal dengan dukungan masyarakat, sekolah serta keluarga.

Dalam pelaksaaan Sekolah ramah Anak perlu dibuat tim pelaksana program, dapat dibuat struktur organisasi yang bertugas sebagai koordinator sekolah ramah anak, sehingga diharapkan dengan adanya koordinator tersebut pelaksanaan program sekolah ramah anak dapat optimal.12 Pelaksanaan SRA membutuhkan perencanaan yang baik salah satunya adalah perlu dibentuk tim khusus yang mengurusi hal itu.

\section{Indikator Sekolah Ramah Anak}

Menurut Kristanto, dkk. Sekolah Ramah Anak ini bisa terwujud apabila pusat pendidikan (sekolah, keluarga dan masyarakat) bisa bahu membahu membangun Sekolah Ramah Anak (SRA) ini. Keluarga adalah komunitas terdekat bagi anak didik. Lingkungan keluarga yang ideal bagi anak adalah sebuah lingkungan keluarga yang harmonis, sehat baik lahir maupun batin. Lingkungan semacam ini hanya dapat tercipta manakala sebuah keluarga dapat memenuhi beberapa indikator sebagai berikut:

“a. Mampu memberikan hidup yang layak bagi (sandang, pangan, papan), kesehatan dan pendidikan yang memadai bagi anak. b. Mampu memberikan ruang kepada anak untuk berkreasi, berekspresi, dan berpartisipasi sesuai dengan tingkat umur dan kematangannya. c. Mampu memberikan perlindungan dan rasa aman bagi anak. d. Dalam sebuah keluarga yang harmonis, sejahtera dan terlindungi anak akan tumbuh dan berkembang secara

10 Kristanto, dkk. Identifikasi Model Sekolah Ramah Anak (Sra) Jenjang Satuan Pendidikan Anak Usia Dini Se-Kecamatan Semarang Selatan. Artikel dimuat dalam jurnal “Jurnal Penelitian PAUDIA", Volume 1 No. 1 Tahun 2011.

${ }^{11}$ Ibid.

12 Kiki, dkk., Implementasi Sekolah Ramah Anak (SRA) Pada Sekolah Percontohan Di SD Pekunden 01 Kota Semarang Sebagai Upaya Untuk Mendukung Program Kota Layak Anak (KLA). Artikel ini dmuat dalam "Jurnal ISOSPOL" Tahun 2016. 
wajar dan mampu mengoptimakan setiap potensi yang ada dalam dirinya. e. Lingkup selanjutnya adalah lingkungan (masyarakat). Lingkungan masyarakat yang mampu melindungi, nyaman dan aman akan sangat mendukung perkembangan anak. Anak sebagai pribadi yang berkembang dan mencari jati diri. Dalam pencariannya anak mempunyai kecenderungan untuk mencoba hal baru serta mencari pengakuan dari sekitarnya. Dalam kerangka ini anak seringkali berusaha meniru atau menjadi beda dengn sekitarnya. f. Sebuah komunitas yang sehat bagi anak adalah komunitas yang mampu menerima dan menghargai anak sebagai pribadi, apa adanya. Komunitas ini juga harus mengakomodir kepentingan anak untuk berekspresi, berapresiasi dan berpartisipasi. Selain itu yang tak kalah penting adalah bagaimana komunitas mampu memberikan perlindungan pada anak sehingga anak meraasa aman tinggal dan berinteraksi di dalam komunitasnya."13

Jelaslah bahwa untuk mengembangkan Sekolah Ramah Anak (SRA) diperlukan sinergitas antara (sekolah, keluarga dan masyarakat) yang merupakan tri pusat pendidikan sebagaimana yang dituliskan oleh Ki Hajar Dewantara. Pengembangan SRA tidak akan terlaksana dengan baik apabila dilaksanakan secara sepihak, oleh karena itu dibutuhkan kerjasama yang baik dari semua pihak,

Lebih lanjut menurut Kristanto untuk mencapai itu semua diperlukan indiaktor untuk bisa mencapainya, diantaranya adalah sebagai berikut: a. Inklusif secara proaktif, yang meliputi: 1) Secara proaktif mencari semua anak yang termarginalisasi dari pendidikan. 2) Mempromosikan dan membantu anak untuk memonitor hak-hak dan kesejahteraan semua anak di masyarakat 3) Menghargai keberagaman dan memastikan kesetaraan kesempatan. 4) Memberikan pendidikan yang bebas biaya dan wajib serta murah dan aksesibel. 5) Sehat, Aman dan Protektif b. Fasilitas toilet yang bersih, yang meliputi: 1) Akses kepada air minum yang bersih. 2) Tidak ada kuman fisik atau gangguan. 3) Pencegahan HIV dan AIDS dan non diskriminasi. 4) Partisipasi Masyarakat c. Terfokus pada keluarga: 1) Bekerja untuk memperkuat keluarga sebagai pemberi asuhan dan pendidikan utama bagi anak. 2) Membantu anak, orang tua dan guru membangun hubungan harmonis dan kolaboratif. d. Berbasis komunitas, yang meliputi: 1) Mendorong kemitraan setempat dalam pendidikan. 2) Bertindak dalam dan dengan masyarakat untuk kepentingan. e. Efektif dan berpusat pada anak 1) Bertindak menurut kepentingan terbaik tiap anak. 2) Peduli kepada anak "seluruhnya"; kesehatan, status gizi dan kesejahteraan. 3) Peduli tentang apa yang terjadi kepada anak sebelum mereka masuk sekolah dan setelah pulang dari sekolah. 4) Metode yang kreatif di dalam ruang kelas. f. Kesetaraan gender: 1) Mempromosikan kesetaraan gender dalam penerimaan dan prestasi. 2) Bukan hanya kesempatan yang sama tetapi kesetaraan. 3) Menghilangkan stereotipe 
gender. 4) Menjamin fasilitas, kurikulum, buku dan pengajaran yang sesuai untuk anak perempuan."

Untuk mencapai tujuan Sekolah Ramah Anak beberapa hal di atas dapat dijadikan sebagai salah satu alternatifnya.

\section{Ciri-ciri Sekolah Ramah Anak}

Menurut Kristianto, ada beberapa ciri-ciri Sekolah Ramah Anak yang ditinjau dari beberapa aspek:

“a. Sikap terhadap murid; Perlakuan adil bagi murid laki-laki dan perempuan, cerdas-lemah, kaya-miskin, normal-cacat, anak pejabat-anak buruh, Penerapan norma agama, sosial dan budaya setempat. Serta Kasih sayang kepada murid, memberikan perhatian bagi mereka yang lemah dalam proses belajar karena memberikan hukuman fisik maupun nonfisik bisa menjadikan anak trauma. Saling menghormati hak-hak anak, baik antar murid, antar tenaga, kependidikan serta antara tenaga kependidikan dan murid. b. Metode Pembelajaran: Terjadi proses belajar sedemikian rupa sehingga siswa merasakan senang mengikuti pelajaran, tidak ada rasa takut, cemas dan waswas, siswa menjadi lebih aktif dan kreatif serta tidak merasa rendah diri karena bersaing dengan teman siswa lain. Terjadi proses belajar yang efektif yang dihasilkan oleh penerapan metode pembelajaran yang variatif dan inovatif. Misalnya: belajar tidak harus di dalam kelas, guru sebagai fasilitator proses belajar menggunakan alat bantu untuk meningkatkan ketertarikan dan kesenangan dalam pengembangan kompetensi, termasuk lingkungan sekolah sebagai sumber belajar (pasar, kebun, sawah, sungai, laut, dll). c. Proses belajar mengajar didukung oleh media ajar seperti buku pelajaran dan alat bantu ajar/peraga sehingga membantu daya serap murid. Guru sebagai fasilitator menerapkan proses belajar mengajar yang kooperatif, interaktif, baik belajar secara individu maupun kelompok. Terjadi proses belajar yang partisipatif. Murid lebih aktif dalam proses belajar. Guru sebagai fasilitator proses belajar mendorong dan memfasilitasi murid dalam menemukan cara/ jawaban sendiri dalam suatu persoalan. d. Murid dilibatkan dalam berbagai aktifitas yang mengembangkan kompetensi dengan menekankan proses belajar melalui berbuat sesuatu (learning by doing, demo, praktek, dll). e. Penataan Kelas; Murid dilibatkan dalam penataan bangku, dekorasi dan ilustrasi yang menggambarkan ilmu pengetahuan, dll. Penataan bangku secara klasikal (berbaris ke belakang) mungkin akan membatasi kreatifitas murid dalam interaksi sosial dan kerja dikursi kelompok, Murid dilibatkan dalam menentukan warna dinding atau dekorasi dinding kelas sehingga murid menjadi betah di dalam kelas, Murid dilibatkan dalam memajang karya murid, hasil ulangan/ test, bahan ajar dan buku sehingga artistik dan menarik serta menyediakan space untuk baca (pojok baca). Bangku dan kursi sebaiknya ukurannya disesuaikan dengan ukuran postur anak Indonesia serta mudah untuk digeser guna menciptakan kelas yang 
dinamis. f. Lingkungan Kelas; Murid dilibatkan dalam mengungkapkan gagasannya dalam menciptakan lingkungan sekolah (penentuan warna dinding kelas, hiasan, kotak saran, majalah dinding, taman kebun sekolah), Tersedia fasilitas air bersih, higienis dan sanitasi, fasilitas kebersihan dan fasilitas kesehatan, Fasilitas sanitasi seperti toilet, tempat cuci, disesuaikan dengan postur dan usia anak, Di sekolah diterapkan kebijakan/peraturan yang mendukung kebersihan dan kesehatan. Kebijakan/peraturan ini disepakati, dikontrol dan dilaksanakan oleh semua murid (dari-oleh-dan untuk murid)" ${ }^{14}$

Demikianlah beberapa ciri-ciri Sekolah Ramah Anak yang dapat dijadikan sebagai panduan bagi pengelola pendidikan.

\section{Prinsip Mengembangkan Sekolah Ramah Anak}

Menurut Kristianto ada beberapa prinsip yang mungkin bisa diterapkan untuk mengembagkan sekolah yang ramah anak, diantaranya adalah:

“a. Sekolah dituntut untuk mampu menghadirkan dirinya sebagai sebuah media, tidak sekedar tempat yang menyenangkan bagi anak untuk belajar. $b$. Dunia anak adalah "bermain". Dalam bermain itulah sesungguhnya anak melakukan proses belajar dan bekerja. Sekolah merupakan tempat bermain yang memperkenalkan persaingan yang sehat dalam sebuah proses belajarmengajar. c. Sekolah perlu menciptakan ruang bagi anak untuk berbicara mengenai nilai-nilai positif. Tujuannya agar terjadi dialektika antara nilai yang diberikan oleh pendidikan kepada anak. d. Para pendidik tidak perlu merasa terancam dengan penilaian peserta didik karena pada dasarnya nilai tidak menambah realitas atau substansi para obyek, melainkan hanya nilai. Nilai bukan merupakan benda atau unsur dari benda, melainkan sifat, kualitas, suigeneris yang dimiliki obyek tertentu yang dikatakan "baik". e. Hasil pertemuan dapat menjadi bahan refleksi dalam sebuah materi pelajaran yang disampaikan di kelas. Cara ini merupakan siasat bagi pendidik untuk mengetahui kondisi anak karena disebagian masyarakat, anak dianggap investasi keluarga, sebagai jaminan tempat bergantung di hari tua". 15

Prinsip membangun Sekolah Ramah Anak di atas bahwsanya sekolah harus dapat dijadikan sebagai media belajar, sekolah merupakan tempat bermain bagi anak, sekolah merupakan ruang untuk mengembangkan nilai-nilai positif, pendidik tidak perlu merasa terancam dengan penilaian peserta didik, melakukan refleksi bersama untuk mengetahui perkembangan anak.

Untuk mewujudkan Sekolah Ramah Anak menurut Wuri, ada enam indikator yang dikembangkan untuk mengukur capaian SARA. Indikator tersebut meliputi: 1) kebijakan SRA, 2) pelaksanaan kurikulum, 3) pendidikan dan tenaga kependidikan terlatih hak-hak anak, 4) sarana dan prasarana SRA, 5)

14 Kristanto, dkk. Identifikasi Model Sekolah Ramah Anak (Sra) Jenjang Satuan Pendidikan Anak Usia Dini Se-Kecamatan Semarang Selatan. Artikel dimuat dalam jurnal "Jurnal Penelitian PAUDIA", Volume 1 No. 1 Tahun 2011.

15 Ibid. 
partisipasi anak, dan 6) partisipasi orang tua, lembaga masyarakat, dunia usaha, pemangku kepentingan lainnya, dan alumni. idealnya keenam indikator tersebut harus dipenuhi dalam rangka mewujudkan SRA. ${ }^{16}$ Jelaslah dari kedua pendapat tersebut di atas bahwasanya dalam mengembangkan SRA diperlukan dukuangan dari semua pihak yang berupa kebijakan, fasilitas maupun kerjasama dari orang tua, lembaga masyarakat, dunia usaha, pemangku kepentingan lainnya, dan alumni.

Dengan masih tingginya kasus kekerasan yang terjadi selama kurun waktu tahun 2013 Komisi Nasional Perlindungan Anak (Komnas PA) melaporkansebanyak 3.023kasus pelanggaran hak anak terjadi di Indonesia dan 58 persen atau 1.620 anak jadi korban kejahatan seksual. Dilihat dari klasifikasi usia, dari 3.023 kasus tersebut, sebanyak 1.291 kasus (45 persen) terjadi pada anak berusia 13 hingga 17 tahun, korban berusia 6 hingga 12 tahun sebanyak 757 kasus (26 persen), dan usia 0 hingga 5 tahun sebanyak 849 kasus atau 29 persen (kompas). ${ }^{17}$ Berdasarkan data ini terlihat masih tingginya kasus kekearasan yang dilakukan terhadap anak.

Merujuk pada hasil riset dari KPAI tersebut menunjukkan bahwa sekolah hingga detik ini belum bisa menjadi tempat yang ramah bagi anak (siswa). Meskipun disebut sebagai lembaga pendidikan, akan tetapi kekerasan justru sering lahir dari tempat ini. Hal tersebut tentu sangat kontra produktif dengan makna sekolah itu sendiri, yaitu sebagai tempat untuk belajar, bukan tempat untuk melakukan kekerasan. Sekolah yang seharusnya menjadi tempat begitu menyenangkan bagi anak, karena di lembaga pendidikan inilah anak-anak akan di didik untuk saling mengenal, menyayangi satu dengan yang lain bukan untuk bermusuhan atau saling menindas. ${ }^{18}$ Dengan demikian pengembangan SRA menjadi sangat mutlak untuk menuntaskan serta mencegah terjadinya berbagai kekerasan yang dilakukan terhadap anak serta untuk memenuhi hak-haknya.

Selanjutnya dalam kegiatan pembelajaran, pendidik dapat mengimplementasikan pendidikan ramah anak yang berbasis $3 \mathrm{P}$ (Provisi, Proteksi, dan Partisipasi) dalamproses pembelajaranya dapat lebih meningkatkan pada peran siswa dalam keaktifannya berekspresi, bertanya, menjawab, berargumentasi, bahkan siswa diperkenankan untuk menginterupsi pada saat pendidik sedang menjelaskan. Pendidikan ramah anak yang diimplementasikan di sekolah secara langsung maupun tidak langsung dapat membentuk karakter siswa. Pendidikan karakter tidak saja merupakan tuntutan

16 Wuri W., dkk., Implementasi Pemenuhan Hak Anak Melalui Sekolah Ramah Anak. Artikel ini dimuat dalam “Jurnal Civics: Media Kajian Kewarganegaraan”. Vol. 15 No. 1 Tahun 2018, h. 32.

17 Agus Yulianto. Pendidikan Ramah Anak: Studi Kasus SDIT Nur Hidayah Surakarta. Artikel dimuat dalam “At-Tarbawi: Jurnal Kajian Kependidikan Islam" Vol. 1, No. 2, Juli-Desember 2016, h. 45. 18 Ibid. 
undang-undang dan peraturan pemerintah, tetapi juga oleh agama, karena setiap agama mengajarkan karakter atau akhlak pada pemeluknya19.

\section{Pengertian Pendidikan Anak Usia Dini}

Menurut UU Sisdiknas No. 20/2003, Pasal. 1 ayat 14 berbunyi: "Pendidikan Anak Usia Dini merupakan suatu upaya pembinaan yang ditujukan kepada anak sejak lahir sampai dengan usia enam tahun yang dilakukan melalui pemberian rangsangan pendidikan untuk membantu pertumbuhan dan perkembangan jasmani dan rohani agar anak memiliki kesiapan dalam memasuki pendidikan lebih lanjut yang diselenggarakan pada jalur formal, nonformal, dan informal." 20

Pendidikan Anak Usia Dini adalah suatu proses pembinaan tumbuh kembang anak usia lahir hingga enam tahun secara menyeluruh, yang mencakup aspek fisik dan non fisik dengan memberikan rangsangan bagi perkembangan jasmani, rohani (moral dan spiritual), motorik, akal fikir, emosional, dan sosial yang tepat dan benar agar anak tumbuh dan berkembang secara optimal. Adapun upaya yang dilakukan mencakup stimulasi intelektual, pemeliharaan kesehatan, pemberian nutrisi, dan penyediaan kesempatan-kesempatan yang luas untuk mengeksplorasi dan belajar secara aktif Pendidikan Anak Usia Dini merupakan salah satu bentuk penyelenggaraan pendidikan yang menitikberatkan pada peletakan dasar ke arah pertumbuhan dan perkembangan fisik (koordinasi motorik halus dan kasar), kecerdasan (daya pikir, daya cipta, kecerdasan emosi, kecerdasan spiritual), sosio emosional (sikap dan perilaku serta agama) bahasa dan komunikasi, sesuai dengan keunikan dan tahaptahap perkembangan yang dilalui oleh anak usia dini. ${ }^{21}$

Rentangan anak usia dini menurut Pasal 28 UU Sisdiknas No.20/2003 ayat 1 adalah 0-6 tahun. Sementara menurut kajian rumpun keilmuan PAUD dan penyelenggaraannya di beberapa negara, PAUD dilaksanakan sejak usia 0-8 tahun. Adapun ruang Lingkup Pendidikan Anak Usia Dini, yaitu:

a. Masa Bayi - Infant (0-1 tahun)

b. Masa Balita-Toddler (2-3 tahun)

c. Masa prasekolah - Preschool/Kindergarten children (3-6 tahun)

d. Masa Sekoah Dasar Awal-Early Primary School (6-8 tahun). ${ }^{22}$

Ada dua tujuan diselenggarakannya pendidikan anak usia dini yaitu:

a. Tujuan utama untuk membentuk anak Indonesia yang berkualitas, yaitu anak yang tumbuh dan berkembang sesuai dengan tingkat perkembangannya sehingga memiliki kesiapan yang optimal di dalam

19 Hardi P.,Peran Bimbingan dan Konseling Dalam Pendidikan Ramah Anak Terhadap Pembentukan Karakter Sejak Usia Dini. Artikel ini dimuat dalam "Jurnal CARE (Children Advisory Research and Education)" Volume 04 Nomor 1 Juni 2016.

20 Ibid.

21 Ibid.

22 Ibid. 
memasuki pendidikan dasar serta mengarungi kehidupan di masa dewasa.

b. Tujuan penyerta untuk membantu menyiapkan anak mencapai kesiapan belajar (akademik) di sekolah. ${ }^{23}$

Sedangkan tujuan umum dan khusus didirikannya PAUD adalah sebagai berikut:

a. Tujuan umum didirikannya PAUD adalah "Mengembangkan berbagai potensi anak sejak dini sebagai persiapan untuk hidup dan mampu menyesuaikan diri dengan lingkungannya di masa depan, termasuk siap memasuki pendidikan dasar".

b. Tujuan khusus didirikannya PAUD adalah:

1) Mampu merangsang perkembangan fisiknya, antara lain: menggunakan keterampilan gerak tubuh, melakukan ibadah, mengenal dan percaya kepada Tuhan YME dan mencintai sesama.

2) Mampu merangsang perkembangan moral, antara lain: menggunakan bahasa untuk pemahaman bahasa pasif dan dapat berkomunikasi secara efektif yang bermanfaat dalam proses berpikir dan belajar.

3) Mampu merangsang perkembangan kognitif, antara lain: berpikir logis, kritis, kreatif mengenal lingkungan alam, sosial, memberi alasan, berperan di masyarakat dan menghargai keragaman sosial budaya.

4) Mampu merangsang perkembangan sosial anak, antara lain: peka terhadap irama, nada, birama, berbagai bunyi, bertepuk tangan, serta menghargai hasil karya yang kreatif.

5) Penigkatan kualitas kesehatan status gizi anak, melalui kegiatan PMT dan peningkatan pengetahuan dan pemahaman orang tua tentang tumbuh kembang anak. Kemudian manfaat PAUD bagi anak pra sekolah adalah mereka yang belum berumur 6 tahun bisa bersekolah melalui PAUD ini, karena didalam PAUD itu sendiri bukan hanya pendidikan formal yang diajarkan melainkan pendidikan non formal. Pada dasarnya mengarahkan pendidikan kepada anak sebelum umur 6 tahun itu lebih baik, karena anak bisa merasakan kegiatan bersekolah meskipun belum mencapai umur. Misalkan, mereka bisa bermain dengan teman sebayanya dan pendidik pun akan mengarahkan ke arah permainan yang bermanfaat bagi si anak. Jadi, manfaat PAUD bagi anak pra sekolah, mereka bisa merasakan sekolah sebelum memasuki sekolah yang sebenarnya dan mempunyai bekal pendidikan yang telah di ajarkan di PAUD. ${ }^{24}$

Oleh karena itu, hasil yang diharapkan dari PAUD adalah anak mendapatkan rangsangan dan kesempatan serta peluang yang besar untuk 
mengembangkan potensi sepenuhnya. Anak yang merupakan subyek sentral memiliki bakat, minat dan potensi yang tidak terbatas untuk dikembangkan oleh pihak-pihak yang bertanggungjawab terhadapnya di dalam suasana penuh kasih sayang, aman, terpenuhi kebutuhan dasarnya, dan kaya stimulasi. Programprogram Pendidikan anak usia dini di Indonesia dewasa ini antara lain dilaksanakan melalui kegiatan : a. Taman kanak-kanak (TK) b. Raudhatul Athfal (RA) c. Kelompok Bermain (KB) d. Taman Penitipan Anak (TPA) e. Pos Pelayanan Terpadu (Posyandu) f. Pos-pos PAUD. g. Sekolah Dasar awal h. Bina Keluarga Balita (BKB) i. Dan satuan pos PAUD lain sejenis. ${ }^{25}$

Richen Dorji (2008) yang telah melakukan kajian terhadap lembaga pendidikan formal di Bhutan dengan mengaplikasikan model sekolah ramah anak pada beberapa lembaga formal jenjang sekolah Dasar di Bhutan yang mencakup komponen program pembelajaran yang didasarkan pada konvensi hak anak internasional. Penelitian tersebut memberikan implikasi terhadap peningkatan hasil prestasi siswa dan peningkatan kualitas mengajar guru yang ramah anak. Selain itu hasil penelitian Phnom Penh, Kamboja juga telah mengukur keberhasilan peningkatan kualitas pendidikan dengan mengaplikasikan konsep sekolah ramah anak yang sudah dijadikan sebuah kebijakan pemerintah Kamboja. Peningkatan itu terlihat dari fasilitas sekolah yang sudah memperhatikan kebersihan dan higienitas bagi para siswanya. Sanitasi lingkungan sekolah yang sudah teratur dan peningkatan kualitas mengajar guru yang non diskriminasi. ${ }^{26}$

Hasil identifikasi satuan PAUD di Kecamatan Semarang Selatan yang berkaitan dengan konsep sekolah ramah anak yang meliputi sikap terhadap murid, metode pembelajaran, penataan kelas dan lingkungan yang sehat untuk jenjang satuan Pendidikan Anak usia Dini dapat diklasifikasikan ke dalam beberapa kategori, dari 32 Satuan PAUD yang ada di kecamatan Semarang Selatan, terdapat Sebanyak 28 satuan PAUD sudah menunjukan perlakuan dan penerapan norma agama, sosial, dan budaya setempat dan hanya empat satua PAUD belum menunjukan perlakuan tersebut. Selain itu dalam perlakuan terhadap murid dengan indikator kasih sayang kepada murid, memberikan perhatian bagi mereka yang lemah dalam proses belajar. Memberikan hukuman fisik maupun non fisik bisa menjadikan anak trauma sudah ditunjukan oleh sebanyak 25 satuan PAUD dan sisanya sebanyak tujuh satuan PAUD. ${ }^{27}$ Selanjutnya, hasil penelitian ratnasari, dkk. menunjukkan bahwa: Sekolah Ramah Anak dapat diartikan sebagai sekolah atau tempat pendidikan yang secara sadar menjamin dan memenuhi hak-hak anak dalam setiap aspek kehidupan secara

\footnotetext{
25 Ibid.

26 Ibid.

27 Ibid.
} 
terencana dan bertanggung jawab. ${ }^{28}$ Berdasarkan beberapa hasil penelitian ini dirasa perlu untuk mengembangkan SRA di PAUD untuk menjamin dan memenuhi hak-hak anak.

\section{Simpulan}

Berdasarkan beberapa kajian teori serta beberapa penelitian yang dilakukan berkaitan dengan Sekolah Ramah Anak diperoleh kesimpulan yaitu, Pengembangan Sekolah Ramah Anak di PAUD adalah suatu keniscayaan sebagai upaya untuk mengoptimalkan pertumbuhan dan perkembangan fisik maupun mentalnya secara tepat agar mampu menerima dan memberi respon terhadap stimulasi yang didapatkan dari lingkungan. Kemudian, untuk melaksanakan Sekolah Ramah Anak diperlukan perencanaan yang baik, oleh karena itu perlu dibentuk tim khusus agar kegiatannya terorganisir dengan baik. Selain itu pengembangan Sekolah Ramah Anak di PAUD sebagai upaya untuk menjamin dan memenuhi hak-hak anak. Serta Pengembangan Sekolah Ramah Anak di PAUD dilaksanakan sebagai upaya untuk mengurangi serta mengatasi maraknya kekerasan terhadap anak.

\section{Referensi}

Agus Yulianto. Pendidikan Ramah Anak: Studi Kasus SDIT Nur Hidayah Surakarta. Artikel dimuat dalam "At-Tarbawi: Jurnal Kajian Kependidikan Islam" Vol. 1, No. 2, Juli-Desember 2016,

Ayu Oktira Diyanti, dkk. Lingkungan Ramah Anak pada Sekolah Taman KanakKanak. Dimuat dalam “Jurnal RUAS” Vol. 12 No. 2, Desember 2014.

Hardi P., Peran Bimbingan dan Konseling Dalam Pendidikan Ramah Anak Terhadap Pembentukan Karakter Sejak Usia Dini. Artikel ini dimuat dalam "Jurnal CARE (Children Advisory Research and Education)" Volume 04 Nomor 1 Juni 2016.

Kementerian Pemberdayaan Perempuan dan Perlindungan Anak RI. Panduan Sekolah Ramah Anak. Deputi Tumbuh Kembang Anak Kementerian Peberdayaan Perempuan dan Perlindungan Anak Tahun 2015., h. 14.

Kiki, dkk., Implementasi Sekolah Ramah Anak (SRA) Pada Sekolah Percontohan

Di SD Pekunden 01 Kota Semarang Sebagai Upaya Untuk Mendukung Program Kota Layak Anak (KLA). Artikel ini dmuat dalam "Jurnal ISOSPOL" Tahun 2016.

Kristanto, dkk. Identifikasi Model Sekolah Ramah Anak (Sra) Jenjang Satuan Pendidikan Anak Usia Dini Se-Kecamatan Semarang Selatan. Artikel dimuat dalam jurnal "Jurnal Penelitian PAUDIA", Volume 1 No. 1 Tahun 2011.

28 Ratnasari, dkk., Implementasi Penerapan Sekolah Ramah Anak Pada Penyelenggaraan Pendidikan Sekolah Dasar. Artikel ini dimuat dalam "Artikel dimuat dalam "The 5th Urecol Proceeding", UAD Yogyakarta 18 Februari 2017. 
Ratnasari, dkk. Implementasi Penerapan Sekolah Ramah Anak Pada Penyelenggaraan Pendidikan Sekolah Dasar. Artikel dimuat dalam “The 5th Urecol Proceeding", UAD Yogyakarta 18 Februari 2017.

Senowarsito, dkk., Implementasi Pendidikan Ramah Anak Dalam Konteks Membangun Karakter Siswa Di Sekolah Dasar Negeri Di Kota Semarang. Artikel ini dimuat dalam "FPBS IKIP PGRI Semarang" Vol. 6 No. 1 Tahun 2012.

Wuri W., dkk., Implementasi Pemenuhan Hak Anak Melalui Sekolah Ramah Anak. Artikel ini dimuat dalam "Jurnal Civics: Media Kajian Kewarganegaraan". Vol. 15 No. 1 Tahun 2018. 